\title{
REVIEW
}

\section{Ex vivo T-cell depletion in allogeneic hematopoietic stem cell transplant: past, present and future}

\author{
A Saad and LS Lamb
}

The most common cause of post-transplant mortality in patients with hematological malignancy is relapse, followed by GvHD, infections, organ toxicity and second malignancy. Immune-mediated complications such as GvHD continue to be challenging, yet amenable to control through manipulation of the T-cell compartment of the donor graft with subsequent immunomodulation after transplant. However, risk of both relapse and infection increase concomitantly with T-cell depletion (TCD) strategies that impair immune recovery. In this review, we discuss the clinical outcome of current and emerging strategies of TCD in allogeneic hematopoietic stem cell transplant that have developed during the modern transplantation era, focusing specifically on ex vivo strategies that target selected T-cell subsets.

Bone Marrow Transplantation (2017) 52, 1241-1248; doi:10.1038/bmt.2017.22; published online 20 March 2017

\section{INTRODUCTION}

High-dose chemo/radiotherapy followed by allogeneic hematopoietic stem cell transplant (HSCT) provides a potentially curative treatment for a variety of hematological diseases. The commonest cause of post-transplant mortality is relapse of neoplastic disease (41\%), GvHD (12\%), infections (11\%) and organ toxicity. ${ }^{1}$ Although attenuated conditioning regimens can decrease the risk of organ toxicity, alloreactive lymphocytes of the graft can mediate a potentially life-threatening GvHD due to HLA dissimilarity. ${ }^{2,3}$ Moreover, the majority of patients $(\sim 70 \%)$ do not have matched sibling donor ${ }^{4}$ and thus require alternative donors that could have greater degrees of HLA disparity, increasing the risk of GvHD. Indeed, the initial attempts using unmanipulated marrow from alternative donors resulted in severe GvHD. ${ }^{5,6}$ Preclinical models showed that both $\mathrm{CD} 4+$ and $\mathrm{CD} 8+\mathrm{T}$ cells are capable of mediating lethal GvHD in HLA-incompatible transplants. ${ }^{7}$ The recognition of the graft versus tumor $(\mathrm{GVT})^{8}$ phenomenon after bone marrow (BM) transplantation likely contributed to the increasing use of PBSC grafts in order to exploit the antineoplastic function of the cytotoxic T cells in the PBSC graft (PBSC grafts have one log more T cells than BM grafts). PBSC graft is conceivably easier to collect and has been associated with faster engraftment. ${ }^{9}$ However, the use of PBSC has contributed to an increased risk of GvHD, in particular chronic GvHD. This has been shown in the setting of matched sibling ${ }^{10}$ and matched unrelated donors. ${ }^{9}$ Thus, the concept of separation of GvHD and GVT was coined and captured the attention of several investigators. ${ }^{11}$

\section{METHODS OF GRAFT MANIPULATION}

T cells are major component of the hematopoietic stem cell graft (Figure 1) exerting an adaptive or innate immune response (Table 1). Graft manipulation is commonly done via 'depletion' of T cells that are implicated in GvHD or less commonly 'expansion' of regulatory T cells (Treg: CD3+ CD4+ CD25hi FoxP3+) to reduce GvHD risk, or NK and $\gamma \delta T$ cells to decrease risk of relapse and enhance immune reconstitution (Table 2). Various methods have been employed for TCD (Table 3). Initial attempts to remove the T cells from the hematopoietic graft ex vivo were attempted in the late $1980 \mathrm{~s}^{12}$ via agglutination with soybean lectin and rosetting the residual T cells with sheep $\mathrm{RBC}$, and this was further advanced to the use of T-cell-directed monoclonal antibodies, for example, anti-CD2, CD3, CD5 in combination with panning, immunotoxin, or complement (to enhance elimination of antibody-sensitized cells). ${ }^{12-14}$ These trials using pan-TCD showed initially promising results by marked reduction of risk of GvHD even without the use of post-transplant pharmacological GvHD prophylaxis. However, this was associated with an increased risk of disease relapse seen particularly in patients with CML. ${ }^{15}$ In addition, an increased incidence of graft failure was observed, in both matched related donors, ${ }^{16}$ and alternative donors, ${ }^{17}$ suggesting that donor $\mathrm{T}$ cells are required to counter balance the ability of residual recipient $T$ cells (surviving conditioning regimen) to reject the graft. These findings strongly suggested the same alloreactive $T$ cells responsible for GvHD could also be beneficial in both facilitating engraftment and eliminating residual leukemia through an adoptive immune response of the GVT effect. ${ }^{8}$ Thus aggressive ex vivo pan-TCD seemed not to be optimal even for alternative donor transplants, and subsequent studies have explored the use of modified or targeted TCD that leaves more $T$ cells in the graft combined with post-transplant pharmacological immunosuppression.

Alternative to ex vivo T-cell depletion, serotherapy has been used for in vivo T-cell depletion. This has been done using either as anti-thymocyte globulin (ATG), ${ }^{18}$ or alemtuzumab. ${ }^{19}$ While alemtuzumab use has declined due to increased risk of relapse and engraftment failure in particular with haploidentical (haplo) HSCT, ATG continues to be more frequently used at variable doses. A CIBMTR retrospective analysis showed lower risk of acute and 


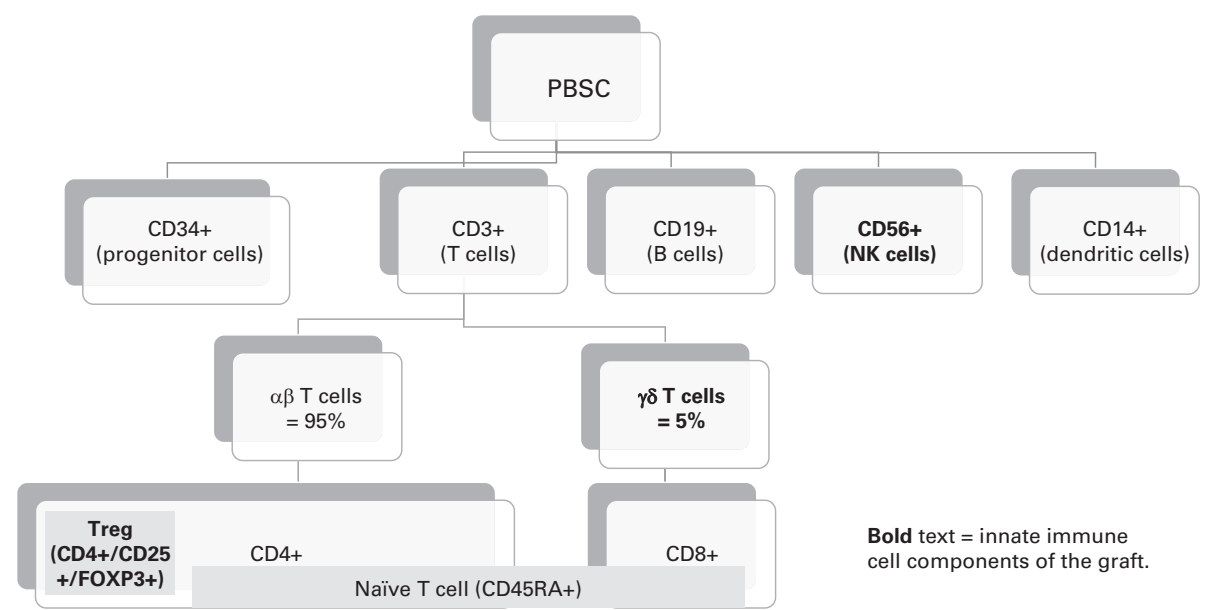

Figure 1. Major components of apheresis and bone marrow grafts with predominately innate lymphocyte components highlighted in bold. A full color version of this figure is available at the Bone Marrow Transplant journal online.

\begin{tabular}{|ll}
\hline Table 1. Immune function of the lymphocytes in the hematopoietic stem cell graft & \\
\hline & Clinical significance \\
\hline Adaptive immune system (antigen-specific) & Fight infection \\
T cells $\rightarrow$ cell-mediated (cellular) immunity. & Kill neoplastic cells (GVT effect) \\
B cells $\rightarrow$ antibody-mediated (humeral) immunity. & Cause GvHD \\
Innate immune system (nonspecific) & Fight infection \\
NK cells. ${ }^{\mathrm{b}}$ & Kill neoplastic cells (GVT effect) \\
Treg & Does not cause GvHD \\
$\gamma \delta$ T cells. &
\end{tabular}

Abbreviations: $\mathrm{GVT}=$ graft versus tumor; $\mathrm{NK}=$ natural killer. ${ }^{\mathrm{a}}$ Also includes granulocytes (neutrophils, eosinophils and basophils), monocytes and macrophages. ${ }^{b} \mathrm{NK}$ cells can have adaptive and innate immune functions.

\begin{tabular}{|ll}
\hline Table 2. & Graft manipulation strategies and their clinical purposes \\
\hline Manipulation strategy & Clinical purpose \\
\hline $\begin{array}{c}\text { Depletion (targeted negative selection) } \\
\text { Pan T-cell depletion }\end{array}$ & $\begin{array}{l}\text { GvHD risk } \\
\text { reduction }\end{array}$ \\
Ex vivo (with or without T-cell add-back) & \\
In vivo serotherapy (ATG or alemtuzumab). & \\
T-cell subset depletion & \\
CD8+ T-cell depletion. & \\
CD3/CD19 cell depletion. & \\
$\alpha \beta$ T-cell/CD19 cell depletion. & \\
Naive T-cell depletion. & \\
Depletion of immune cells (indirectly) & \\
CD34+ positive selection. & GrHD risk \\
Inclusion (positive selection/expansion) & reduction \\
Treg cells & Relapse/infection \\
NK cell & risk reduction \\
$\gamma \delta$ T cells & \\
\hline Abbreviations: ATG = anti-thymocyte globulin; NK = natural killer. \\
\hline
\end{tabular}

chronic GvHD and higher risk of relapse with either method of serotherapy compared with T-cell replete transplant (PBSC or $\mathrm{BM}){ }^{20}$ Another evolving method of in vivo alloreactive T-cell depletion is use of post-transplant cyclophosphamide (PTCy). This method has been clinically introduced with T-cell replete haplo $\mathrm{BM}$ transplant ${ }^{21}$ and is becoming increasingly used with PBSC graft $^{22}$ as well as with HLA-matched ${ }^{23}$ transplant. Detailed discussion of in vivo T-cell depletion is beyond the scope of this article.

\section{T-CELL DEPLETION AND CD34+ CELL SELECTION IN HLA-MATCHED HSCT}

The initial trials of ex vivo TCD using monoclonal antibodies was associated with high risk of GvHD. ${ }^{24}$ Investigators soon realized that additional treatment of the $\mathrm{T}$ cells with complement or immunotoxins (along with anti-T-cell antibody) is essential to eliminate the $T$ cells from the graft. This approach resulted in $\sim 2-3$ log reduction of the T cells and was associated with lower risk of GvHD of 10-20\% without pharmacological GvHD prophylaxis. ${ }^{25}$ Graft failure was also a hindrance to initial clinical studies using ex vivo T-cell depletion of BM graft even with HLA-matched donors. ${ }^{16,26}$ Subsequent data from Memorial Sloan-Kettering Cancer Center (MSKCC) showed encouraging results with low risk of GVHD and no increased risk of relapse after myeloablative BM transplant. ${ }^{27,28}$ A National Marrow Donor Program analysis of patients who underwent BM transplant from HLA-matched unrelated donor between 1987 and 1990 included data on 95 patients who underwent TCD. ${ }^{29}$ This showed TCD was associated with less risk of acute and chronic GvHD, higher risk of secondary graft failure and comparable survival outcome to T-cell replete marrow transplant. The Center for International Blood and Marrow Transplant Research (CIBMTR) also analyzed data of 2254 patients who underwent HLA-matched transplant with or without T-cell depletion. ${ }^{8}$ In this seminal analysis, the 
Table 3. Methods of T-cell depletion

Ex vivo methods

Negative selection of T cells

Soybean lectin agglutination with E-rosette depletion.

Antibody-mediated

Monoclonal antibody with complement or immunotoxin.

Monoclonal antibody with immunomagnetic beads.

Positive selection of CD34+ cells

Monoclonal antibody with immunomagnetic beads)
In vivo methods

Polyclonal ATG

Atgam (horse)

Thymoglobulin (rabbit)

ATG-Fresenius (rabbit)

Monoclonal antibody

Alemtuzumab (anti-CD52).

Abbreviation: ATG = anti-thymocyte globulin.

\begin{tabular}{|c|c|c|c|c|c|c|c|}
\hline $1998^{91}$ & 31 & BM & Phase II & None & $6 \%$ & $6 \%$ & $\begin{array}{l}\text { ATG used in addition to } \\
\text { ex vivo T-cell depletion } \\
\text { No graft failure } \\
\text { DFS at } 4 \text { years (AML in CR1 } \\
\text { under age of } 40 \text { years): } 81 \%\end{array}$ \\
\hline $2005^{68}$ & 405 & $\mathrm{BM}$ & $\begin{array}{l}\text { Randomized multicenter phase III } \\
\text { (TCD with CSA versus CSA/MTX) }\end{array}$ & $\begin{array}{c}39 \text { versus } 63 \% \\
(P<0.0001)\end{array}$ & No difference. & $\begin{array}{l}\text { Relapse of CML: } 20 \\
\text { versus 7\% }(P=0.009)\end{array}$ & $\begin{array}{l}\text { DFS at } 3 \text { years: } 27 \% \text { and } 34 \% \\
(P=0.16) \\
\text { CMV infection: } 28 \text { Versus } 17 \% \\
(P=0.023)\end{array}$ \\
\hline $2008^{27}$ & 49 & $\begin{array}{l}\text { PBSC/ } \\
\text { BM }\end{array}$ & Retrospective & $\begin{array}{l}6 \% \text { (any } \\
\text { aGvHD) }\end{array}$ & $2 \%$ & & $\begin{array}{l}\text { Graft failure: } 9 \% \\
\text { OS at } 3 \text { years: } 37 \% \\
\text { NRM at } 2 \text { years: } 30 \%\end{array}$ \\
\hline $2015^{28}$ & 102 & PBSC & Retrospective & $16 \%$ & $4 \%$ (1 year) & $16 \%$ & $\begin{array}{l}\text { Graft failure: } 4 \% \\
\text { OS at } 5 \text { years: } 49 \% \\
\text { DFS at } 5 \text { years: } 48 \% \\
\text { NRM at } 5 \text { years: } 33 \%\end{array}$ \\
\hline
\end{tabular}

phenomenon of graft versus leukemia effect was emphasized by showing higher relapse rate among TCD group.

Investigators also explored the use of CD34+ cell selection rather than TCD in order to enhance the elimination of other lymphocyte or immune cell components in the graft that could be implicated in the pathogenesis of GvHD. ${ }^{30}$ This interest became notable with the emergence of PBSC grafts as an alternative to BM grafts, in particular when the former was shown to be associated with increased risk of chronic GvHD. ${ }^{9,31}$ Myeloablative regimen has been preferred with TCD to mitigate risk of engraftment failure. In 2005, the Blood and Marrow Transplantation Clinical Trials Network (BMT-CTN) initiated a multicenter phase II trial of myeloablative PBSC transplant on $\mathrm{AML}$ patients in complete remission $(n=44)$ (BMT-CTN 0303) with CD34+ cell selection and no other pharmacological GvHD prophylaxis. ${ }^{32}$ The study showed successful engraftment of all accrued patients with low incidence of acute and chronic GVHD. The result of this study (BMT-CTN 0303) was compared with the cohort of BMT-CTN 0101 trial that involved T-cell replete HSCT (with calcineurin inhibitor (CNI)-based GvHD prophylaxis regimen). ${ }^{33}$ This showed no statistical difference in the rate of grades II-IV aGvHD. However, the rate of cGvHD (at 2 years) was significantly lower in the
TCD patients ( 19 versus $50 \%, P<0.001$ ). There were no differences in the risk of engraftment failure, relapse, non-relapse mortality (NRM), disease-free survival (DFS), or overall survival (OS). Two studies have also compared the outcome of TCD versus T-cell replete HSCT (retrospective comparison between data from MSKCC and the MD Anderson Cancer Center) showed lower risk of acute and chronic GvHD in the TCD group with no difference in DSF and $\mathrm{OS}^{34,35}$ It is to be noted that discrepancies in the outcome of these studies (Table 4) may be attributed to difference in the efficiency (log depletion) of $T$ cells, HLA disparity (low resolution testing was only used in the earlier studies), and different patient population and conditioning regimens. With the increasing use of PTCy, BMT-CTN 1301 study (NCT02345850) was initiated randomizing HLA-matched transplant (sibling or unrelated) into 3 arms; CD34+ selection, CNI-based regimen, PTCy. Results of this trial would be pivotal in comparing ex vivo TCD and alloreactive TCD utilizing PTCy.

\section{CD8+ T-CELL DEPLETION}

Since the initial results of ex vivo TCD remained suboptimal with risk of poor or delayed immune reconstitution and engraftment 
Table 5. Studies of ex vivo CD8+ cell depletion in HLA-matched HSCT

\begin{tabular}{|c|c|c|c|c|c|c|}
\hline $\begin{array}{l}\text { Year } \\
\text { published }\end{array}$ & $n$ & Graft type & Study design & $a \mathrm{GvHD}$ (grades II-IV) & Relapse & Other findings \\
\hline $1990^{93}$ & 36 & BM & Phase II & $28 \%$ & $\begin{array}{c}11 \% \text { (none of the } 13 \\
\text { cases with CML relapsed) }\end{array}$ & $\begin{array}{l}\text { Graft failure: } 8 \% \\
\text { OS at } 2 \text { years: } 57 \%\end{array}$ \\
\hline $1994^{94}$ & 38 & BM & $\begin{array}{l}\text { Randomized double-blinded trial of CD8 } \\
+ \text { depletion versus none) }\end{array}$ & $\begin{array}{c}20 \% \text { (CD8+ depletion) } \\
\text { versus } 80 \%\end{array}$ & $10 \%$ in both arms & $\begin{array}{l}\text { Graft failure: } 10 \% \text { (CD8 } \\
+ \text { depletion) versus } \\
\text { none } \\
\text { DFS at } 3 \text { years similar } \\
(37 \%)\end{array}$ \\
\hline $1998^{95}$ & 40 & DLI (salvage) & Phase II & $15 \%$ & $\mathrm{~N} / \mathrm{A}$ & $\begin{array}{l}\text { Response: } 80 \% \text { (in CML } \\
\text { and } \mathrm{MM} \text { ) }\end{array}$ \\
\hline $2002^{96}$ & 18 & $\begin{array}{l}\text { DLI } \\
\text { (prophylactic) }\end{array}$ & $\begin{array}{l}\text { Randomized trial of CD8+ depleted DLI } \\
\text { versus none) given } 6 \text { months post- } \\
\text { transplant }\end{array}$ & $\begin{array}{l}\text { None }(C D 8+\text { depleted }) \\
\text { versus } 56 \% \text { in control } \\
\text { arm }\end{array}$ & $\begin{array}{c}11 \% \text { in CD } 8+\text { depleted } \\
\text { arm versus } 33 \% \text { in control } \\
\text { arm }\end{array}$ & \\
\hline $2004^{97}$ & 9 & DLI (salvage) & Phase II & $10 \%$ & N/A & $\begin{array}{l}\text { Response: } 44 \% \\
\text { (including all } 3 \\
\text { patients with } \mathrm{CML} \text { ) }\end{array}$ \\
\hline $2004^{36}$ & 41 & PBSC & Phase II & $61 \%$ & $5 \%$ & $\begin{array}{l}\text { Engraftment: } 100 \% \\
\text { CGvHD: } 50 \% \\
\text { EFS at } 2 \text { years: } 57 \%\end{array}$ \\
\hline
\end{tabular}

failure, attempts were made to selectively deplete CD8+ T cells as the effector cytotoxic cells that mediate GvHD tissue injury. However, CD8+ cell depletion studies (Table 5) failed to mitigate the risk of GvHD as evidenced by risk of acute GvHD grades II-IV $61 \%$ in a phase II study of HLA-matched PBSC transplantation. ${ }^{36}$ These data suggested that the distinction between GvHD and GVT is not a simple dichotomy of T-cell subsets (CD4+ and CD8+). ${ }^{36,37}$ The CD8+ cell depletion also likely depleted CD8+ NK cells $(\sim 20-30 \%$ of total NK cells) and CD8+ $\Leftrightarrow \gamma \delta$ T cells (20\%).

\section{T-CELL DEPLETION WITH T-CELL ADD-BACK}

The earliest attempt to exploit the concept of adoptive immunotherapy by infusion of add-back immune cells was done by the Fred Hutchinson Cancer Research Center group when they performed a study testing the impact of infusion of add-back 'bone marrow buffy coat' after 'unmanipulated' BM transplantation (BMT). ${ }^{38}$ The purpose of this approach was to explore the potential anti-leukemic effect of the add-back of immune cells to decrease risk of relapse after BMT. However, increased risk of GvHD hindered further progress of this approach. Interest in this strategy was revived in the era of TCD. Clinical trials using addback donor T-cell infusion following ex vivo TCD HSCT was done at the National Institute of Health, USA. ${ }^{39-42}$ The most updated results from this group reported data of 138 patients with hematological malignancies who received myeloablative TCD PBSC transplant from an HLA- identical sibling donor. ${ }^{42}$ In this study, one or two add-back products were infused as $1 \times 10^{7} \mathrm{~T}$ cells per $\mathrm{kg}$ between day +45 and/or day +100 . With a median follow up of 4 years, the OS and DFS, relapse and NRM were $58 \%$, $46 \%, 40 \%$ and $20 \%$, respectively. The incidence of grades II-IV aGvHD and cGvHD were $39 \%$ and $36 \%$ respectively. In another prospective study, children with HLA-matched or mismatched unrelated PBSC transplant $(n=19)$ received T-cell add-back following TCD transplant. ${ }^{43}$ CNI alone was used for GvHD prophylaxis and the risk of grades II-IV aGVHD and extensive CGVHD was 16 and $0 \%$. All patients engrafted and NRM at 1 year was $6 \%$ with 1 -year OS of $82 \%$. More recently, suicide gene (caspase-9) programming of add- back $T$ cells has enabled elimination of $T$ cells (upon treatment with suicide geneactivating drug) upon development of severe GVHD. ${ }^{44}$ Results of this approach used in 10 pediatric patients shows favorable protection against viral infection after a 16 -month follow up. ${ }^{45}$
This approach continued to be evaluated in an ongoing clinical trial (NCT01744223). Another clinical trial (NCT02500550) is evaluating the effect of photodynamic depletion/inactivation of alloreactive $T$ cells in add-back infusion. ${ }^{46}$

\section{T-CELL DEPLETION AND CD34+ CELL SELECTION IN HAPLO HSCT}

One of the earliest studies of $T$-cell replete haplo BMT $(n=35)$ reported by The Royal Marsden Hospital (UK) revealed a very high risk of graft failure and GVHD. ${ }^{47}$ Subsequent similar studies by the Fred Hutchinson Cancer Research Center group showed that mismatching at two out of six loci or more has the same detrimental consequences. ${ }^{2,5}$ Initial attempts at TCD depletion were concurrently being tested to overcome the HLA disparity barrier with a 1981 report from MSKCC showing successful haplo BMT in an infant with AML after ex vivo TCD using differential agglutination with soybean agglutinin and sheep RBC rosette depletion. ${ }^{48}$ No GVHD occurred after this transplant. Subsequently, a separate study reported successful engraftment of two out of three patients with SCID receiving haplo donor BM grafts. ${ }^{49}$ Using the same method (soybean agglutination and E-rosetting), Perugia University (Italy) introduced the use of the 'CD34+ mega dose' concept in the early 1990s in an effort to overcome the risk of engraftment failure encountered with TCD. G-CSF mobilized stem cells were T-cell depleted and added to the BM graft to enrich the CD34+ stem cell dose (mega dose approach). ${ }^{48}$ With the advent of monoclonal antibodies (mAbs) against the TCR in early 1990s, several studies combined either TCD or CD34+ selection methods with systemic ATG and pharmacological GVHD prophylaxis (CNI with or without corticosteroid) showing improved results over previous attempts. ${ }^{50-55}$ With these approachs grades II-IV aGVHD was reduced to 13 to $40 \%$, engraftment failure $\sim 10 \%$ and OS at or below $50 \%$ (Table 6). Recently, the use of high-dose post-transplant cyclophosphamide following infusion of a T-cell replete graft is revolutionizing haplo HSCT. $^{21,22}$ However, there remain several unmet needs to improve haplo HSCT outcome such as improving post-transplant immune reconstitution, which may also decrease relapse rate (in particular with the use of reduced intensity conditioning regimens). 


\begin{tabular}{|c|c|c|c|c|c|c|c|}
\hline $\begin{array}{l}\text { Year } \\
\text { published }\end{array}$ & $n$ & Graft type & $\begin{array}{l}\text { Study } \\
\text { design }\end{array}$ & GVHD (grades II-IV) & cGVHD & Relapse & Other findings \\
\hline $1996^{50}$ & 40 & BM & Phase II & $36 \%$ & $\begin{array}{c}17 \% \\
\text { (extensive) }\end{array}$ & $\begin{array}{l}11 \% \text { (at } 2 \\
\text { years). }\end{array}$ & $\begin{array}{l}\text { Engraftment: } 93 \% \text { (similar to historical } \\
\text { control of } n=17, P=0.12 \text { ) } \\
\text { OS at } 5 \text { years: } 40 \%\end{array}$ \\
\hline $1997^{52}$ & 72 & BM & Phase II & $16 \%$ & $\begin{array}{l}35 \% \\
\text { (extensive in } \\
8 \% \text { ) }\end{array}$ & $32 \%$ & $\begin{array}{l}\text { Engraftment: } 88 \% \\
\text { OS at } 2 \text { years: } 55 \text { and } 27 \% \text { in low- and } \\
\text { high-risk groups }(P=0.05)\end{array}$ \\
\hline $1998^{54}$ & 43 & $\begin{array}{l}\text { PBSC (mega dose) } \\
+ \text { BM (only } n=28 \text { ) }\end{array}$ & Phase II & $0 \%$ & $0 \%$ & $30 \%$ & $\begin{array}{l}\text { Engraftment: } 100 \% \\
\text { NRM: } 40 \%\end{array}$ \\
\hline $2004^{51}$ & 201 & $\mathrm{BM}$ & Phase II & $13 \%$ & $15 \%$ & $31 \%$ & $\begin{array}{l}\text { Engraftment: } 98 \% \\
\text { NRM ( } 5 \text { years): } 51 \% \\
\text { OS at } 5 \text { years: } 19 \%\end{array}$ \\
\hline $2006^{98}$ & 34 & PBSC (mega dose) & Phase II & 13 & 12 & $41 \%$ & $\begin{array}{l}\text { Engraftment: } 91 \% \\
\text { OS at } 2 \text { years: } 26 \%\end{array}$ \\
\hline
\end{tabular}

\begin{tabular}{|c|c|c|c|c|c|c|}
\hline $2014^{83}$ & 23 & PBSC & $\begin{array}{l}\text { Phase II (children with non- } \\
\text { malignant diseases) }\end{array}$ & $\begin{array}{l}13 \% \text { (none was } \\
\text { grade III or IV) }\end{array}$ & $\begin{array}{l}\text { Not reported (except for } \\
\text { graft failure rate of } 17 \% \text { ) }\end{array}$ & $\begin{array}{l}\text { Engraftment failure (primary): } 17 \% \\
\text { CGVHD: } 0 \% \text { ( } 18 \text { months follow up) } \\
\text { NRM: } 9 \% \\
\text { DFS at } 2 \text { years: } 91 \%\end{array}$ \\
\hline $2015^{82}$ & $\begin{array}{l}37 \text { (27 MUD, } \\
\text { and } 10 \\
\text { haplo) }\end{array}$ & PBSC & $\begin{array}{l}\text { Phase II (children with } \\
\text { immunodeficiency } \\
\text { disorders) }\end{array}$ & $22 \%$ & $\begin{array}{l}\text { Not reported (except for } \\
\text { graft failure rate of } 27 \% \text { ) }\end{array}$ & $\begin{array}{l}\text { Engraftment failure (primary and } \\
\text { secondary): } 27 \% \text { (salvaged by second } \\
\text { transplant) } \\
\text { CGVHD: } 5 \% \text { ( } 15 \text { months follow up). } \\
\text { NRM: } 3 \% \\
\text { OS at } 1 \text { year: } 97 \% \\
\text { Similar outcome of MUD and haplo }\end{array}$ \\
\hline
\end{tabular}

\section{CD3+/CD19+ AND a $\beta$ T-CELL/CD19+ CELL DEPLETION}

The rationale of the initial combined depletion of donor CD3+ T-cell and CD19+ B cells is to eliminate the T cells that mediate GVHD, and B cells that are implicated in EBV-driven posttransplantation lymphoproliferative disorders and possibly decreasing risk of cGVHD as well. Based on initial promising data of CD3+/CD19+ cell depletion at St Jude Children's Research Hospital (Memphis, TN, USA), ${ }^{56,57}$ the University of Tubingen group performed clinical studies utilizing this approach with haplo HSCT with resulting risk of grades II-IV aGVHD of 50\%. ${ }^{58,59}$ One study of haplo HSCT on adult patients $(n=29)$ utilized CliniMACS device (microbeads CD3+/CD19+ depletion method) without post-transplant immunosuppression ${ }^{58}$ and the study reported favorable engraftment and donor chimerism at 1 month post transplant. Grades II-IV aGVHD was observed in 48\% and NRM was $20 \%$. The same German group later reported results of a prospective multicenter phase II study using the same method of CD3+/CD19+ cell depletion with haplo HSCT in adult patients $(n=61) .{ }^{59}$ In this study, the incidences of grades II-IV aGVHD and
cGVHD were 46 and $18 \%$ respectively with NRM at 2 years of $42 \%$. The cumulative incidence of relapse/progression at 2 years was $31 \%$. The OS at 2 years was $28 \%$.

The circulating CD3+ T cells are either a $\beta$ T cells (95\%), or $\gamma \delta$ T cells $(5 \%) .{ }^{60}$ The $a \beta$ T cells are implicated in adaptive immune response that mediates GVHD, while $\gamma \delta T$ cells, being part of innate immune system, are not implicated in causing GVHD. ${ }^{61,62}$ With the advent of monoclonal antibody depletion technology, interest was directed to depletion methods that only eliminate $a \beta T$ cells, sparing $\gamma \delta$ T cells and NK cells. ${ }^{57}$ The $a \beta$ T-cell depletion began with the discovery of T10B9, later known as T10B9.1A-31/ MEDI-500, a short-acting non-mitogenic murine immunoglobulin M kappa (IgMк) mAb directed against the TCR a $\beta$ complex (discovered by University of Kentucky). ${ }^{63}$ The first lot of T10B9 was extracted from mouse ascites and approved by the US FDA (Food and Drug Administration) for T-cell depletion using complement-mediated lysis under BB-IND-4279. ${ }^{64-66}$ T10B9 modulates the $a \beta$ but not the $\gamma \delta T C R$, in contrast to OKT3 which binds to the $\varepsilon$ (epsilon) portion of the CD3 receptor and modulates the entire epitope, thus depleting CD3+ T cells (both $\alpha \beta$ and 
$\gamma \delta \mathrm{T}$ cells). Immune reconstitution studies revealed that NK cell recovery was significantly greater in patients that received a $\beta$ TCD grafts than those who received unmanipulated grafts through the first year post transplant. ${ }^{67}$ T10B9-based TCD transplant was evaluated in a multicenter BM depletion trial sponsored by the National Heart, Lung and Blood Institute. Although neutrophil recovery, GVHD, grades III-IV toxicities, and hospital days were reduced or improved in the TCD group, CML relapse and $C M V$ reactivation tended to be higher. ${ }^{68}$ Sparing of $\gamma \delta T$ cells allowed transplantation of a partially T-cell depleted marrow graft, which resulted in favorable homeostatic reconstitution of $\gamma \delta T$ cells in a significant subset of patients compared with that observed with patients receiving OKT3-depleted grafts. ${ }^{69}$ Decreased relapse rate was noted among haplo HSCT using a $\beta$ TCD (T10B9) compared with haplo CD3+ pan TCD (using OKT3). ${ }^{51}$ A subset of patients that received haplo a $\beta T C D$ transplant showed homeostatic reconstitution of increased peripheral blood $\gamma \delta$ T-cell counts that correlated with showed a significant improvement in relapse-free survival. ${ }^{66,69}$ The survival advantage associated with high circulating numbers of of $\gamma \delta T$ cells was found to be durable over seven years following HSCT. ${ }^{70}$ These finding implied potential anti-neoplastic activity of the $\gamma \delta T$ cells. Preclinical and clinical studies have confirmed the anti-neoplastic effect of $\gamma \delta$ T-cell against hematological malignancies ${ }^{71-74}$ as well as other solid tumors. ${ }^{75-77}$ The utilization of $\gamma \delta \mathrm{T}$ cells in immunotherapy has been reviewed before. ${ }^{62}$ Preservation of $\gamma \delta T$ cells can also potentially protect against infections. $^{78,79}$

More recently, the CliniMACS device (Miltenyi Biotec, Bergisch Gladbach, Germany) was introduced using immunomagnetic microbead depletion (using the IgG clone BMA-031) with resulting 3-4 log reduction of the $\alpha \beta$ T cells and B cells. ${ }^{80}$ The efficacy of this depletion strategy was tested in in 200 procedures performed over 3 years in one published study. ${ }^{81}$ Clinical studies have been performed using $\alpha \beta$ T-cell/CD19+ B cell depletion approach mainly in the pediatric population in Europe (Table 7). ${ }^{57,82,83}$ Notably, one clinical study of pediatric patients with primary immunodeficiency syndromes used a $\beta$ TCD/CD19+ BCD of HLAmatched unrelated and haplo PBSC transplantation showed favorable T-cell recovery with most patients having peripheral blood T-cell count $>500 /$ ul by day $+120 . .^{82}$ In this study, the risk of primary or secondary engraftment failure was $27 \%$ (all cases salvaged by second transplant), NRM was $3.3 \%$ and OS at 1 year was $97 \%$. Another study used similar approach in haplo PBSC HSCT without pharmacological GVHD prophylaxis showed comparable results. ${ }^{83}$ Recent findings by Airoldi confirmed the homeostatic reconstitution of $\gamma \delta$ T cells following a $\beta$ T-cell/CD19 $+B$ cell depletion in children receiving haplo HSCT. ${ }^{84}$

\section{FUTURE DIRECTIONS}

It is likely the future of transplant therapy will involve more strategies such Chimeric Antigen Receptor (CAR) T-cell therapy, $\mathrm{Bi}$-specific T-cell engagers, and checkpoint inhibitors to control relapse following allo HSCT. ${ }^{85}$ The adoptive use of Treg $^{86}$ and suicide gene manipulation may improve the risk of GVHD post transplant. ${ }^{44}$ Naive $T$ cells (CD45RA+/CD62L+) are mature un-sensitized $T$ cells were shown to be implicated in causing GVHD in preclinical models. ${ }^{87} \mathrm{~A}$ phase II clinical trial showed that selective depletion of naïve T cells decreases risk of cGVHD. ${ }^{88}$ Other experimental models suggest that different subtypes of functional $T$ cells can be generated from human induced pluripotent stem cells via in vitro cellular manipulation laying foundation of potential anti-neoplastic patient-specific T-cell therapy. ${ }^{89}$ The utilization of $\gamma \delta$ T- cells to mitigate the risk of relapse and to enhance immune reconstitution after allo HSCT continued to be under investigation. Results of phase I studies using add-back of $a \beta$ T-cell- depleted product (following haplo
PBSC transplant with post-transplant cyclophosphamide is awaited (NCT02193880).

\section{CONFLICT OF INTEREST}

AS discloses grant support (American Porphyria foundation), consultation (Medpace Inc), research support (Astellas and Fate Therapeutics), honoraria (Alxion, and Spectrum), and royalty for licensing of intellectual property (Incysus Biomedical). LSL is a scientific founder of Incysus, Ltd and a member of their Scientific Advisory Board.

\section{REFERENCES}

1 Wingard JR, Majhail NS, Brazauskas R, Wang Z, Sobocinski KA, Jacobsohn D et al. Long-term survival and late deaths after allogeneic hematopoietic cell transplantation. J Clin Oncol 2011; 29: 2230-2239.

2 Anasetti C, Amos D, Beatty PG, Appelbaum FR, Bensinger W, Buckner CD et al. Effect of HLA compatibility on engraftment of bone marrow transplants in patients with leukemia or lymphoma. N Engl J Med 1989; 320: 197-204.

3 Anasetti C, Beatty PG, Storb R, Martin PJ, Mori M, Sanders JE et al. Effect of HLA incompatibility on graft-versus-host disease, relapse, and survival after marrow transplantation for patients with leukemia or lymphoma. Hum Immunol 1990; 29: 79-91.

4 Gragert L, Eapen M, Williams E, Freeman J, Spellman S, Baitty R et al. HLA match likelihoods for hematopoietic stem-cell grafts in the U.S. registry. N Engl J Med 2014; 371: 339-348.

5 Beatty PG, Clift RA, Mickelson EM, Nisperos BB, Flournoy N, Martin PJ et al. Marrow transplantation from related donors other than HLA-identical siblings. $N$ Engl J Med 1985; 313: 765-771.

6 Gajewski J, Cecka M, Champlin R. Bone marrow transplantation utilizing HLA-matched unrelated marrow donors. Blood Rev 1990; 4: 132-138.

7 Korngold R, Sprent J. T cell subsets and graft-versus-host disease. Transplantation 1987; 44: 335-339.

8 Horowitz MM, Gale RP, Sondel PM, Goldman JM, Kersey J, Kolb HJ et al. Graft-versus- leukemia reactions after bone marrow transplantation. Blood 1990; 75: $555-562$.

9 Anasetti C, Logan BR, Lee SJ, Waller EK, Weisdorf DJ, Wingard JR et al. Peripheralblood stem cells versus bone marrow from unrelated donors. N Engl J Med 2012; 367: 1487-1496.

10 Bensinger WI, Martin PJ, Storer B, Clift R, Forman SJ, Negrin R et al. Transplantation of bone marrow as compared with peripheral-blood cells from HLA-identical relatives in patients with hematologic cancers. N Engl J Med 2001; 344: 175-181.

11 Mackinnon S, Papadopoulos EB, Carabasi MH, Reich L, Collins NH, Boulad F et al. Adoptive immunotherapy evaluating escalating doses of donor leukocytes for relapse of chronic myeloid leukemia after bone marrow transplantation: separation of graft-versus-leukemia responses from graft-versus-host disease. Blood 1995; 86: 1261-1268.

12 Frame JN, Collins NH, Cartagena T, Waldmann H, O'Reilly RJ, Dupont B et al. T cell depletion of human bone marrow. Comparison of Campath-1 plus complement, anti-T cell ricin A chain immunotoxin, and soybean agglutinin alone or in combination with sheep erythrocytes or immunomagnetic beads. Transplantation 1989; 47: 984-988.

13 Champlin RE, Passweg JR, Zhang MJ, Rowlings PA, Pelz CJ, Atkinson KA et al. T-cell depletion of bone marrow transplants for leukemia from donors other than HLA-identical siblings: advantage of T-cell antibodies with narrow specificities. Blood 2000; 95: 3996-4003.

14 Prentice HG. OKT3 incubation of donor marrow for prophylaxis of acute graft-versus-host disease (GvHD) in allogeneic bone marrow transplantation. J Clin Immunol 1982; 2: 148S-153S.

15 Goldman JM, Gale RP, Horowitz MM, Biggs JC, Champlin RE, Gluckman E et al. Bone marrow transplantation for chronic myelogenous leukemia in chronic phase. Increased risk for relapse associated with T-cell depletion. Ann Intern Med 1988; 108: 806-814.

16 Kernan NA, Bordignon C, Heller G, Cunningham I, Castro-Malaspina H, Shank B et al. Graft failure after T-cell-depleted human leukocyte antigen identical marrow transplants for leukemia: I. Analysis of risk factors and results of secondary transplants. Blood 1989; 74: 2227-2236.

17 Ash RC, Horowitz MM, Gale RP, van Bekkum DW, Casper JT, Gordon-Smith EC et al. Bone marrow transplantation from related donors other than HLA-identical siblings: effect of T cell depletion. Bone Marrow Transplant 1991; 7: 443-452.

18 Bacigalupo A, Lamparelli T, Bruzzi P, Guidi S, Alessandrino PE, di Bartolomeo P et al. Antithymocyte globulin for graft-versus-host disease prophylaxis in transplants from unrelated donors: 2 randomized studies from Gruppo Italiano Trapianti Midollo Osseo (GITMO). Blood 2001; 98: 2942-2947. 
19 Chakraverty R, Orti G, Roughton M, Shen J, Fielding A, Kottaridis P et al. Impact of in vivo alemtuzumab dose before reduced intensity conditioning and HLA-identical sibling stem cell transplantation: pharmacokinetics, GVHD, and immune reconstitution. Blood 2010; 116: 3080-3088.

20 Soiffer RJ, Lerademacher J, Ho V, Kan F, Artz A, Champlin RE et al. Impact of immune modulation with anti-T-cell antibodies on the outcome of reducedintensity allogeneic hematopoietic stem cell transplantation for hematologic malignancies. Blood 2011; 117: 6963-6970.

21 Luznik L, O'Donnell PV, Symons HJ, Chen AR, Leffell MS, Zahurak M et al. HLA-haploidentical bone marrow transplantation for hematologic malignancies using nonmyeloablative conditioning and high-dose, posttransplantation cyclophosphamide. Biol Blood Marrow Transplant 2008; 14: 641-650.

22 Solomon SR, Sizemore CA, Sanacore M, Zhang X, Brown S, Holland HK et al. Total body irradiation-based myeloablative haploidentical stem cell transplantation is a safe and effective alternative to unrelated donor transplantation in patients without matched sibling donors. Biol Blood Marrow Transplant 2015; 21: 1299-1307.

23 Kanakry CG, Tsai HL, Bolanos-Meade J, Smith BD, Gojo I, Kanakry JA et al. Singleagent GVHD prophylaxis with posttransplantation cyclophosphamide after myeloablative, HLA-matched BMT for AML, ALL, and MDS. Blood 2014; 124: 3817-3827.

24 Martin PJ, Hansen JA, Thomas ED. Preincubation of donor bone marrow cells with a combination of murine monoclonal anti-T-cell antibodies without complement does not prevent graft-versus-host disease after allogeneic marrow transplantation. J Clin Immunol 1984; 4: 18-22.

25 Filipovich AH, Vallera D, McGlave P, Polich D, Gajl-Peczalska K, Haake R et al. T cell depletion with anti-CD5 immunotoxin in histocompatible bone marrow transplantation. The correlation between residual CD5 negative T cells and subsequent graft-versus-host disease. Transplantation 1990; 50: 410-415.

26 Bordignon C, Keever CA, Small TN, Flomenberg N, Dupont B, O'Reilly RJ et al. Graft failure after T-cell-depleted human leukocyte antigen identical marrow transplants for leukemia: II. In vitro analyses of host effector mechanisms. Blood 1989; 74: 2237-2243.

27 Castro-Malaspina H, Jabubowski AA, Papadopoulos EB, Boulad F, Young JW, Kernan NA et al. Transplantation in remission improves the disease-free survival of patients with advanced myelodysplastic syndromes treated with myeloablative $\mathrm{T}$ cell-depleted stem cell transplants from HLA-identical siblings. Biol Blood Marrow Transplant 2008; 14: 458-468.

28 Tamari R, Chung SS, Papadopoulos EB, Jakubowski AA, Hilden P, Devlin SM et al. CD34- selected hematopoietic stem cell transplants conditioned with myeloablative regimens and antithymocyte globulin for advanced myelodysplastic syndrome: limited graft-versus- host disease without increased relapse. Biol Blood Marrow Transplant 2015; 21: 2106-2114.

29 Kernan NA, Bartsch G, Ash RC, Beatty PG, Champlin R, Filipovich A et al. Analysis of 462 transplantations from unrelated donors facilitated by the National Marrow Donor Program. N Engl J Med 1993; 328: 593-602.

30 Bensinger WI, Buckner CD, Shannon-Dorcy K, Rowley S, Appelbaum FR, Benyunes M et al. Transplantation of allogeneic CD34+ peripheral blood stem cells in patients with advanced hematologic malignancy. Blood 1996; 88: 4132-4138.

31 Champlin RE, Schmitz N, Horowitz MM, Chapuis B, Chopra R, Cornelissen JJ et al. Blood stem cells compared with bone marrow as a source of hematopoietic cells for allogeneic transplantation. IBMTR Histocompatibility and Stem Cell Sources Working Committee and the European Group for Blood and Marrow Transplantation (EBMT). Blood 2000; 95: 3702-3709.

32 Devine SM, Carter S, Soiffer RJ, Pasquini MC, Hari PN, Stein A et al. Low risk of chronic graft- versus-host disease and relapse associated with $\mathrm{T}$ cell-depleted peripheral blood stem cell transplantation for acute myelogenous leukemia in first remission: results of the blood and marrow transplant clinical trials network protocol 0303. Biol Blood Marrow Transplant 2011; 17: 1343-1351.

33 Pasquini MC, Devine S, Mendizabal A, Baden LR, Wingard JR, Lazarus HM et al. Comparative outcomes of donor graft CD34+ selection and immune suppressive therapy as graft-versus- host disease prophylaxis for patients with acute myeloid leukemia in complete remission undergoing HLA-matched sibling allogeneic hematopoietic cell transplantation. J Clin Oncol 2012; 30: 3194-3201.

34 Bayraktar UD, de Lima M, Saliba RM, Maloy M, Castro-Malaspina HR, Chen J et al. Ex vivo $T$ cell-depleted versus unmodified allografts in patients with acute myeloid leukemia in first complete remission. Biol Blood Marrow Transplant 2013; 19: 898-903.

35 Hobbs GS, Hamdi A, Hilden PD, Goldberg JD, Poon ML, Ledesma C et al. Comparison of outcomes at two institutions of patients with ALL receiving ex vivo T-cell-depleted or unmodified allografts. Bone Marrow Transplant 2015; 50: 493-498.

36 Ho VT, Kim HT, Li S, Hochberg EP, Cutler C, Lee SJ et al. Partial CD8+ T-cell depletion of allogeneic peripheral blood stem cell transplantation is insufficient to prevent graft-versus- host disease. Bone Marrow Transplant 2004; 34: 987-994.
37 Coghill JM, Sarantopoulos S, Moran TP, Murphy WJ, Blazar BR, Serody JS. Effector CD4+ $T$ cells, the cytokines they generate, and GVHD: something old and something new. Blood 2011; 117: 3268-3276.

38 Sullivan KM, Storb R, Buckner CD, Fefer A, Fisher L, Weiden PL et al. Graft-versushost disease as adoptive immunotherapy in patients with advanced hematologic neoplasms. N Engl J Med 1989; 320: 828-834.

39 Nakamura R, Bahceci E, Read EJ, Leitman SF, Carter CS, Childs R et al. Transplant dose of $\mathrm{CD} 34(+)$ and $\mathrm{CD} 3(+)$ cells predicts outcome in patients with haematological malignancies undergoing $\mathrm{T}$ cell-depleted peripheral blood stem cell transplants with delayed donor lymphocyte add-back. Br J Haematol 2001; 115: 95-104.

40 Barrett AJ, Mavroudis D, Tisdale J, Molldrem J, Clave E, Dunbar C et al. T celldepleted bone marrow transplantation and delayed $\mathrm{T}$ cell add-back to control acute GVHD and conserve a graft-versus-leukemia effect. Bone Marrow Transplant 1998; 21: 543-551.

41 Savani BN, Rezvani K, Mielke S, Montero A, Kurlander R, Carter CS et al. Factors associated with early molecular remission after $\mathrm{T}$ cell-depleted allogeneic stem cell transplantation for chronic myelogenous leukemia. Blood 2006; 107: 1688-1695.

42 Montero A, Savani BN, Shenoy A, Read EJ, Carter CS, Leitman SF et al. T-cell depleted peripheral blood stem cell allotransplantation with T-cell add-back for patients with hematological malignancies: effect of chronic GVHD on outcome. Biol Blood Marrow Transplant 2006; 12: 1318-1325.

43 Geyer MB, Ricci AM, Jacobson JS, Majzner R, Duffy D, Van de Ven C et al. T cell depletion utilizing $\mathrm{CD} 34(+)$ stem cell selection and $\mathrm{CD} 3(+)$ addback from unrelated adult donors in paediatric allogeneic stem cell transplantation recipients. Br J Haematol 2012; 157: 205-219.

44 Di Stasi A, Tey SK, Dotti G, Fujita Y, Kennedy-Nasser A, Martinez C et al. Inducible apoptosis as a safety switch for adoptive cell therapy. N Engl J Med 2011; 365: 1673-1683.

45 Zhou X, Di Stasi A, Tey SK, Krance RA, Martinez C, Leung KS et al. Long-term outcome after haploidentical stem cell transplant and infusion of T cells expressing the inducible caspase 9 safety transgene. Blood 2014; 123: 3895-3905.

46 Perruccio K, Topini F, Tosti A, Carotti A, Burchielli E, Ruggeri L et al. Optimizing a photoallodepletion protocol for adoptive immunotherapy after haploidentical SCT. Bone Marrow Transplant 2012; 47: 1196-1200.

47 Powles RL, Morgenstern GR, Kay HE, McElwain TJ, Clink HM, Dady PJ et al. Mismatched family donors for bone-marrow transplantation as treatment for acute leukaemia. Lancet 1983; 1: 612-615.

48 Reisner Y, Kapoor N, Kirkpatrick D, Pollack MS, Dupont B, Good RA et al. Transplantation for acute leukaemia with HLA-A and B nonidentical parental marrow cells fractionated with soybean agglutinin and sheep red blood cells. Lancet 1981; 2: 327-331.

49 Reisner Y, Kapoor N, Kirkpatrick D, Pollack MS, Cunningham-Rundles S, Dupont B et al. Transplantation for severe combined immunodeficiency with HLA-A,B,D,DR incompatible parental marrow cells fractionated by soybean agglutinin and sheep red blood cells. Blood 1983; 61: 341-348.

50 Henslee-Downey PJ, Parrish RS, MacDonald JS, Romond EH, Marciniak E, Coffey C et al. Combined in vitro and in vivo $\mathrm{T}$ lymphocyte depletion for the control of graft-versus-host disease following haploidentical marrow transplant. Transplantation 1996; 61: 738-745.

51 Mehta J, Singhal S, Gee AP, Chiang KY, Godder K, Rhee FvF et al. Bone marrow transplantation from partially HLA-mismatched family donors for acute leukemia: single- center experience of 201 patients. Bone Marrow Transplant 2004; 33: 389-396.

52 Henslee-Downey PJ, Abhyankar SH, Parrish RS, Pati AR, Godder KT, Neglia WJ et al. Use of partially mismatched related donors extends access to allogeneic marrow transplant. Blood 1997; 89: 3864-3872.

53 Soiffer RJ, Mauch P, Fairclough D, Alyea E, Anderson K, Fisher D et al. CD6+ T cell depleted allogeneic bone marrow transplantation from genotypically $\mathrm{HLA}$ nonidentical related donors. Biol Blood Marrow Transplant 1997; 3: 11-17.

54 Aversa F, Tabilio A, Velardi A, Cunningham I, Terenzi A, Falzetti F et al. Treatment of high- risk acute leukemia with T-cell-depleted stem cells from related donors with one fully mismatched HLA haplotype. N Engl J Med 1998; 339: 1186-1193.

55 Aversa F, Terenzi A, Tabilio A, Falzetti F, Carotti A, Ballanti S et al. Full haplotypemismatched hematopoietic stem-cell transplantation: a phase II study in patients with acute leukemia at high risk of relapse. J Clin Oncol 2005; 23: 3447-3454.

56 Barfield RC, Otto M, Houston J, Holladay M, Geiger T, Martin J et al. A one-step large-scale method for T- and B-cell depletion of mobilized PBSC for allogeneic transplantation. Cytotherapy 2004; 6: 1-6.

57 Handgretinger R. Negative depletion of CD3(+) and TcRalphabeta(+) T cells. Curr Opin Hematol 2012; 19: 434-439.

58 Bethge WA, Faul C, Bornhauser M, Stuhler G, Beelen DW, Lang P et al. Haploidentical allogeneic hematopoietic cell transplantation in adults using CD3/CD19 
depletion and reduced intensity conditioning: an update. Blood Cells Mol Dis 2008; 40: 13-19.

59 Federmann B, Bornhauser M, Meisner C, Kordelas L, Beelen DW, Stuhler G et al. Haploidentical allogeneic hematopoietic cell transplantation in adults using CD3/CD19 depletion and reduced intensity conditioning: a phase II study. Haematologica 2012; 97: 1523-1531.

60 Carding SR, Egan PJ. Gammadelta T cells: functional plasticity and heterogeneity. Nat Rev Immunol 2002; 2: 336-345.

61 Drobyski WR, Majewski D, Hanson G. Graft-facilitating doses of ex vivo activated gammadelta $T$ cells do not cause lethal murine graft-versus-host disease. Biol Blood Marrow Transplant 1999; 5: 222-230.

62 Lamb LS Jr, Lopez RD. gammadelta T cells: a new frontier for immunotherapy? Biol Blood Marrow Transplant 2005; 11: 161-168.

63 Waid TH, Thompson JS, Siemionow M, Brown SA. T10B9 monoclonal antibody: a short- acting nonstimulating monoclonal antibody that spares gammadelta T-cells and treats and prevents cellular rejection. Drug Des Devel Ther 2009; 3: 205-212.

64 Thompson JS, Pomeroy C, Kryscio RJ, Brown SA, Reece D, Kramer R et al. Use of a T cell- specific monoclonal antibody, T10B9, in a novel allogeneic stem cell transplantation protocol for hematologic malignancy high-risk patients. Biol Blood Marrow Transplant 2004; 10: 858-866.

65 Henslee PJ, Thompson JS, Romond EH, Doukas MA, Metcalfe M, Marshall ME et al. T cell depletion of HLA and haploidentical marrow reduces graft-versus-host disease but it may impair a graft-versus-leukemia effect. Transplant Proc 1987; 19: 2701-2706.

66 Lamb LS Jr, Henslee-Downey PJ, Parrish RS, Godder K, Thompson J, Lee C et al. Increased frequency of TCR gamma delta+T cells in disease-free survivors following $T$ cell-depleted, partially mismatched, related donor bone marrow transplantation for leukemia. J Hematother 1996; 5: 503-509.

67 Keever-Taylor CA, Wagner JE, Kernan NA, Small TN, Carter SL, Thompson JS et al. Comparison of immune recovery in recipients of unmanipulated Versus T-celldepleted grafts from unrelated donors in a multicenter randomized phase II-III trial (T-cell depletion trial). Bone Marrow Transplant 2010; 45: 587-589.

68 Wagner JE, Thompson JS, Carter SL, Kernan NA. Effect of graft-versus-host disease prophylaxis on 3-year disease-free survival in recipients of unrelated donor bone marrow (T-cell Depletion Trial): a multi-centre, randomised phase II-III trial. Lancet 2005; 366: 733-741.

69 Lamb LS Jr, Gee AP, Hazlett LJ, Musk P, Parrish RS, O'Hanlon TP et al. Influence of T cell depletion method on circulating gammadelta $T$ cell reconstitution and potential role in the graft-versus-leukemia effect. Cytotherapy 1999; 1: 7-19.

70 Godder KT, Henslee-Downey PJ, Mehta J, Park BS, Chiang KY, Abhyankar S et al. Long term disease-free survival in acute leukemia patients recovering with increased gammadelta $\mathrm{T}$ cells after partially mismatched related donor bone marrow transplantation. Bone Marrow Transplant 2007; 39: 751-757.

71 Lowdell MW, Lamb L, Hoyle C, Velardi A, Prentice HG. Non-MHC-restricted cytotoxic cells: their roles in the control and treatment of leukaemias. $\mathrm{Br} J$ Haematol 2001; 114: 11-24.

72 Meeh PF, King M, O'Brien RL, Muga S, Buckhalts P, Neuberg R et al. Characterization of the gammadelta $T$ cell response to acute leukemia. Cancer Immunol Immunother 2006; 55: 1072-1080.

73 Wilhelm M, Smetak M, Schaefer-Eckart K, Kimmel B, Birkmann J, Einsele H et al. Successful adoptive transfer and in vivo expansion of haploidentical gammadelta T cells. J Transl Med 2014; 12: 45.

74 Smetak M, Kimmel B, Birkmann J, Schaefer-Eckart K, Einsele H, Wilhelm M et al. Clinical- scale single-step $\mathrm{CD} 4(+)$ and $\mathrm{CD} 8(+)$ cell depletion for donor innate lymphocyte infusion (DILI). Bone Marrow Transplant 2008; 41: 643-650.

75 Liu Z, Eltoum IE, Guo B, Beck BH, Cloud GA, Lopez RD. Protective immunosurveillance and therapeutic antitumor activity of gammadelta $T$ cells demonstrated in a mouse model of prostate cancer. J immunol 2008; 180: 6044-6053.

76 Beck BH, Kim HG, Kim H, Samuel S, Liu Z, Shrestha R et al. Adoptively transferred ex vivo expanded gammadelta-T cells mediate in vivo antitumor activity in preclinical mouse models of breast cancer. Breast Cancer Res Treat 2010; 122: 135-144

77 Braza MS, Klein B. Anti-tumour immunotherapy with Vgamma9Vdelta2 T lymphocytes: from the bench to the bedside. Br J Haematol 2013; 160: 123-132.

78 Vantourout $P$, Hayday A. Six-of-the-best: unique contributions of gammadelta T cells to immunology. Nat Rev Immunol 2013; 13: 88-100.

79 Bonneville M, Scotet E. Human Vgamma9Vdelta2 T cells: promising new leads for immunotherapy of infections and tumors. Curr Opin Immunol 2006; 18: 539-546.

80 Schumm M, Lang P, Taylor G, Kuci S, Klingebiel T, Buhring HJ et al. Isolation of highly purified autologous and allogeneic peripheral CD34+ cells using the CliniMACS device. J Hematother 1999; 8: 209-218.

81 Li Pira G, Malaspina D, Girolami E, Biagini S, Cicchetti E, Conflitti G et al. Selective depletion of alphabeta $T$ cells and $B$ cells for human leukocyte antigen- haploidentical hematopoietic stem cell transplantation. a three-year follow-up of procedure efficiency. Biol Blood Marrow Transplant 2016; 22: 2056-2064.

82 Balashov D, Shcherbina A, Maschan M, Trakhtman P, Skvortsova Y, Shelikhova L et al. Single-center experience of unrelated and haploidentical stem cell transplantation with TCRalphabeta and CD19 depletion in children with primary immunodeficiency syndromes. Biol Blood Marrow Transplant 2015; 21: 1955-1962.

83 Bertaina A, Merli P, Rutella S, Pagliara D, Bernardo ME, Masetti R et al. HLA-haploidentical stem cell transplantation after removal of alphabeta+ $\mathrm{T}$ and B cells in children with nonmalignant disorders. Blood 2014; 124: 822-826.

84 Airoldi I, Bertaina A, Prigione I, Zorzoli A, Pagliara D, Cocco C et al. gammadelta T-cell reconstitution after HLA-haploidentical hematopoietic transplantation depleted of TCR- alphabeta+/CD19+ lymphocytes. Blood 2015; 125: 2349-2358.

85 Villasboas JC, Ansell SM, Witzig TE. Targeting the PD-1 pathway in patients with relapsed classic Hodgkin lymphoma following allogeneic stem cell transplant is safe and effective. Oncotarget 2016; 7: 13260-13264.

86 McDonald-Hyman C, Flynn R, Panoskaltsis-Mortari A, Peterson N, MacDonald KP, Hill GR et al. Therapeutic regulatory T-cell adoptive transfer ameliorates established murine chronic GVHD in a CXCR5-dependent manner. Blood 2016; 128: 1013-1017.

87 Dutt S, Tseng D, Ermann J, George TI, Liu YP, Davis CR et al. Naive and memory T cells induce different types of graft-versus-host disease. J Immunol 2007; 179: 6547-6554.

88 Bleakley M, Heimfeld S, Loeb KR, Jones LA, Chaney C, Seropian S et al. Outcomes of acute leukemia patients transplanted with naive $T$ cell-depleted stem cell grafts. J Clin Invest 2015; 125: 2677-2689.

89 Chang CW, Lai YS, Lamb LS Jr, Townes TM. Broad T-cell receptor repertoire in T- lymphocytes derived from human induced pluripotent stem cells. PLOS ONE 2014; 9: e97335.

90 Young JW, Papadopoulos EB, Cunningham I, Castro-Malaspina H, Flomenberg N, Carabasi $\mathrm{MH}$ et al. T-cell-depleted allogeneic bone marrow transplantation in adults with acute nonlymphocytic leukemia in first remission. Blood 1992; 79: 3380-3387.

91 Papadopoulos EB, Carabasi MH, Castro-Malaspina H, Childs BH, Mackinnon S, Boulad $\mathrm{F}$ et al. T-cell-depleted allogeneic bone marrow transplantation as postremission therapy for acute myelogenous leukemia: freedom from relapse in the absence of graft-versus-host disease. Blood 1998; 91: 1083-1090.

92 Jakubowski AA, Small TN, Kernan NA, Castro-Malaspina H, Collins N, Koehne G et al. T cell- depleted unrelated donor stem cell transplantation provides favorable disease-free survival for adults with hematologic malignancies. Biol Blood Marrow Transplant 2011; 17: 1335-1342.

93 Champlin R, Ho W, Gajewski J, Feig S, Burnison M, Holley G et al. Selective depletion of $\mathrm{CD} 8+\mathrm{T}$ lymphocytes for prevention of graft-versus-host disease after allogeneic bone marrow transplantation. Blood 1990; 76: 418-423.

94 Nimer SD, Giorgi J, Gajewski JL, Ku N, Schiller GJ, Lee K et al. Selective depletion of CD8+ cells for prevention of graft-versus-host disease after bone marrow transplantation. A randomized controlled trial. Transplantation 1994; 57: 82-87.

95 Alyea EP, Soiffer RJ, Canning C, Neuberg D, Schlossman R, Pickett C et al. Toxicity and efficacy of defined doses of $\mathrm{CD} 4(+)$ donor lymphocytes for treatment of relapse after allogeneic bone marrow transplant. Blood 1998; 91: 3671-3680.

96 Soiffer RJ, Alyea EP, Hochberg E, Wu C, Canning C, Parikh B et al. Randomized trial of CD8+ T-cell depletion in the prevention of graft-versus-host disease associated with donor lymphocyte infusion. Biol Blood Marrow Transplant 2002; 8: 625-632.

97 Alyea EP, Canning C, Neuberg D, Daley H, Houde H, Giralt S et al. CD8+ cell depletion of donor lymphocyte infusions using $\mathrm{cd} 8$ monoclonal antibody-coated high-density microparticles (CD8-HDM) after allogeneic hematopoietic stem cell transplantation: a pilot study. Bone Marrow Transplant 2004; 34: 123-128.

98 Marks DI, Khattry N, Cummins M, Goulden N, Green A, Harvey J et al. Haploidentical stem cell transplantation for children with acute leukaemia. $\mathrm{Br} J$ Haematol 2006; 134: 196-201.

99 Handgretinger R. New approaches to graft engineering for haploidentical bone marrow transplantation. Semin Oncol 2012; 39: 664-673.

(c) (1) $€$ This work is licensed under a Creative Commons Attributioncc. NonCommercial-NoDerivs 4.0 International License. The images or other third party material in this article are included in the article's Creative Commons license, unless indicated otherwise in the credit line; if the material is not included under the Creative Commons license, users will need to obtain permission from the license holder to reproduce the material. To view a copy of this license, visit http:// creativecommons.org/licenses/by-nc-nd/4.0/

(c) The Author(s) 2017 